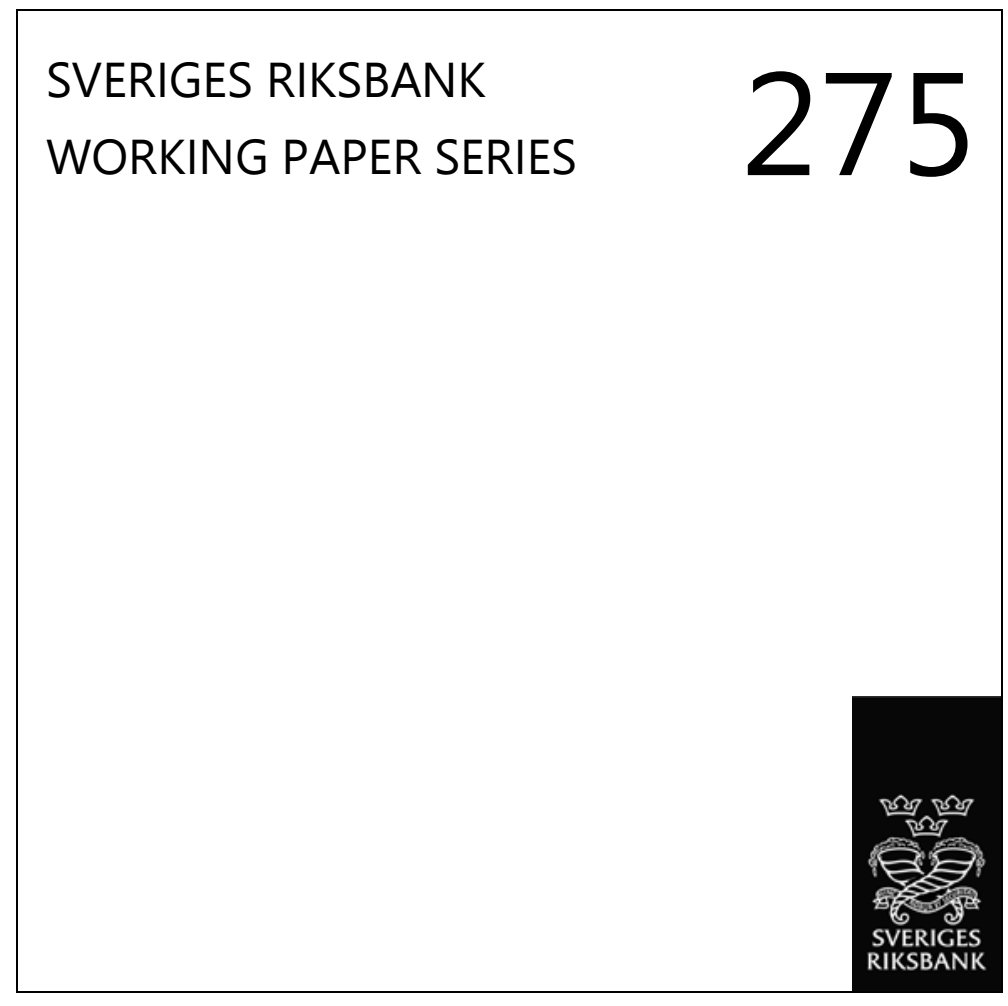

\title{
Business Cycle Implications of Mortgage Spreads
}

Karl Walentin

September 2013 (Updated March 2014) 


\section{WORKING PAPERS ARE OBTAINABLE FROM}

Sveriges Riksbank • Information Riksbank • SE-103 37 Stockholm

Fax international: +4687870526

Telephone international: +4687870100

E-mail: info@riksbank.se

The Working Paper series presents reports on matters in the sphere of activities of the Riksbank that are considered to be of interest to a wider public.

The papers are to be regarded as reports on ongoing studies and the authors will be pleased to receive comments.

The views expressed in Working Papers are solely the responsibility of the authors and should not to be interpreted as reflecting the views of the Executive Board of Sveriges Riksbank. 


\title{
Business Cycle Implications of Mortgage Spreads*
}

\author{
Karl Walentin ${ }^{\dagger}$ \\ Sveriges Riksbank Working Paper Series
}

No. 275

March 2014

\begin{abstract}
How do aggregate quantities at the business cycle frequency respond to shocks to the spread between residential mortgage rates and government bonds? Using a structural VAR approach, we find that mortgage spread shocks impact the real economy by both economically and statistically significant magnitudes: a 100 basis point decline in the spread causes a peak increase in consumption, residential investment and GDP by 1.6 percent, 6.2 percent and 1.9 percent, respectively. These effects are magnified when the policy rate is held fixed, as was the case in the US during the recent implementation of unconventional monetary policy.
\end{abstract}

Keywords: Sources of business cycles, unconventional monetary policy, credit supply, house prices, financial frictions.

JEL codes: E21, E32, E44, E52, R21.

${ }^{*}$ I am grateful to Jan Alsterlind for starting this project off. Thanks to Kristopher Gerardi (the editor) and the referee for valuable suggestions. Thanks also for feedback at many presentations and in private conversations. Warm thanks to Mattias Villani for sharing his VAR code and Jonas Arias, Juan Rubio-Ramírez and Dan Waggoner for sharing their sign and zero restriction code. The views expressed in this paper are solely the responsibility of the author and should not be interpreted as reflecting the views of the Executive Board of Sveriges Riksbank.

${ }^{\dagger}$ E-mail: karl.walentin@riksbank.se. 


\section{Introduction}

What are the quantitative business cycle effects of time variation in the residential mortgage interest rate spread? Surprisingly, this question is almost unexplored in the existing literature despite the substantial cyclical variation of this spread in the data. While Hubbard and Mayer (2009), Guerrieri and Lorenzoni (2011) and Hall (2011a, 2011b) all have referenced the issue, none have empirically documented the relationship between mortgage spreads and aggregate quantities. We define the mortgage spread as the difference between the average interest rate on newly issued mortgages at a given maturity and the government bond rate of the corresponding maturity. By using this definition, we separate the mortgage spread from the term premium. We restrict our analysis to the prime mortgage market. This is not because we think that subprime mortgages are unimportant, but rather because the two markets merit separate analysis.

Why might mortgage rates affect the macroeconomy? Theoretically, the mortgage rate, and thus the mortgage spread, potentially affects aggregate economic variables through several channels: i) house prices and residential investment through the user cost of housing, ii) as one relevant rate in the consumption/savings decision and, iii) the post-interest disposable income of any household with a mortgage. If house prices are affected by mortgage spreads, then housing wealth and collateral values are also affected. In the presence of binding collateral constraints or, more generally, if credit extension is decreasing in household leverage, mortgage spreads will influence spending decisions through this collateral channel.

The motivation for exploring the business cycle effects of residential mortgage spread variation - and, more specifically, innovations to this spread - is threefold. First, this paper seeks to contribute to the general understanding of what drives business cycles and document the quantitative importance of mortgage spread innovations for aggregate variables. ${ }^{1}$ Second, if the mortgage spread affects aggregate variables, then monetary policy should take that into account. Accordingly, the analysis herein also explores how monetary policy historically has responded to mortgage spread innovations. This paper thereby complements Cúrdia and Woodford's (2009) analysis which addresses how monetary policy optimally is conducted in a stylized model with one lending spread that applies to all types of loans. Third, and perhaps most importantly, this paper's research question has bearings on unconventional monetary policy intended to affect the business cycle through the mortgage spread, such as the Federal Reserve's recent purchases of mortgage backed securities (MBS). To our knowledge, this paper is unique in that it empirically quantifies the business cycle effects of mortgage spread innovations without relying on a specific theoretical model.

The US is the primary country of study over the sample period 1983q1-2011q4. We start by documenting the substantial time variation in the mortgage spread and that the spread is countercyclical. Furthermore, the maximum absolute cross-correlation

\footnotetext{
${ }^{1} \mathrm{~A}$ closely related issue is that if mortgage spread variation have non-negligible importance, existing models that abstract from it are misspecified. This problem is probably most severe for estimated structural models that address the role of housing for the business cycle, e.g. Iacoviello and Neri (2011) and Walentin (2013).
} 
occurs when the mortgage spread leads GDP by 2-3 quarters. In other words, the spread is lowest immediately prior to GDP peaks and highest immediately prior to GDP troughs. A very similar pattern has been documented by Kydland et al. (2012) for nominal mortgage rates.

Our main exercise is inspired by Gilchrist et al.'s (2009) and Gilchrist and Zakrajšek's (2012) work on the macroeconomic effects of corporate bond spreads. The role of innovations to mortgage spreads for business cycles is documented by estimating a structural vector autoregression (SVAR). The baseline SVAR includes the following seven variables in levels: consumption, residential investment, GDP, the consumer price index, the mortgage spread, the policy interest rate, and house prices. The identifying restriction is that mortgage spread shocks do not affect aggregate quantities or consumer prices on impact but are allowed to contemporaneously affect the policy rate and house prices.

The mortgage spread impulse responses obtained are consistent with the simple theoretical relationships mentioned above. They are also consistent with an interpretation of mortgage spread shocks as credit supply shocks: aggregate quantities and house prices all decrease following a positive innovation to the spread. A mortgage shock of 100 basis points (bps) yields a decrease of 1.6 percent in consumption, 6.2 percent in residential investment, and 1.9 percent in GDP. These responses are gradual and reach a trough after more than one year. House prices respond faster and decline by 2.6 percent. We find a fast and strong 184 bps offsetting response of the policy rate to the mortgage spread shock. A second exercise documents the effect of mortgage spread shocks in a setting where the policy rate is fixed. This is the relevant context in which to analyze recent unconventional monetary policy. In this exercise, we find that a 100 bps increase in the mortgage spread results in a decline of 2.7 percent in consumption, 15.6 percent in residential investment, 2.4 percent in GDP, and 6.9 percent in house prices. Note that residential investment and house prices are the variables most affected by holding the policy rate fixed.

The importance of mortgage spread shocks is moderate in terms of variance decomposition at business cycle frequencies. Mortgage shocks are most important for the policy rate where it accounts for 25 percent of the variance at short horizons. Roughly 10 percent of consumption, GDP and house price variation is due to the spread shock. In terms of variance decomposition the mortgage spread shock is as important for the business cycle as the excess (corporate) bond premium shock documented in Gilchrist and Zakrajšek (2012).

We find similar results for the UK and Sweden. Mortgage spread innovations also appear both statistically and economically important for these countries. Furthermore, they induce the same qualitative dynamics. However, the mortgage spread shock is more important for aggregate quantities and house prices in these countries compared to the US and its impact is faster. This difference may be because the typical duration of mortgage contracts in the UK and Sweden is much shorter than in the US.

Our results are robust to several variations in both the SVAR specification and the sample period. Perhaps most importantly, the importance of mortgage spread innovations is not diminished when a corporate bond spread is included in the VAR 
and ordered before the mortgage spread. We use an alternative measure of the mortgage spread that accounts for the prepayment option in US mortgages. We change the basic identification approach by using sign restrictions. For a given size of the mortgage spread shock, effects on aggregate quantities are larger for both of these alternative specifications.

To aid in the interpretation of the mortgage spread shock, we estimate a SVAR specification where the quantity of mortgage debt outstanding is added to our baseline VAR. The mortgage spread shocks drive the price and the quantity of credit in opposite directions. This corroborates other indications that mortgage spread shocks should be interpreted as credit supply disturbances.

The takeaways from this paper are: i) business cycle fluctuations are affected by financial frictions in the residential mortgage market, ii) innovations in the mortgage spread appear to capture movements in credit supply that are moderately important for business cycle variation in aggregate quantities and house prices, iii) in general, the policy rate partially offsets mortgage spread innovations, and its variance is to a substantial degree driven by these, and iv) if unconventional monetary policy in the form of asset purchases in mortgage markets succeeds in affecting the mortgage spread, then it has sizable effects on aggregate quantities and house prices. ${ }^{2}$ Similarly, macroprudential policies that affect the mortgage spread will have sizable business cycle effects.

The paper is organized as follows. The remaining part of this section describes the related literature. Section 2 characterizes the mortgage spread. Section 3 contains the quantitative exercises and results. Robustness exercises are documented in Section 4 and Section 5 concludes. Online appendices contain additional material.

\section{$1.1 \quad$ Related literature}

Although their primary focus differs, three papers clearly relate to the present paper as they include empirical analysis of the effects of a household borrowing spread on the macroeconomy. Both Darracq Pariès et al. (2011) and Gerali et al. (2010) estimate a DSGE model using one measure of the retail bank loan rate and another for the retail deposit rate, in addition to standard macro variables. Musso et al. (2011) estimate structural VAR models to compare the US' and the Euro area's monetary transmission mechanisms, with a focus on housing. They include a mortgage rate in their structural VAR models. As detailed in section 3.4, it is critical to use a mortgage spread against a government bond with a matching maturity in order to avoid confounding the short risk-free rate, the term premium and the mortgage spread.

This paper addresses time variation in aggregate mortgage conditions in terms of prices, measured as spreads. This complements the mainly theoretical existing literature that deals with time variation in the quantity dimension of mortgage credit conditions, often measured by the maximum loan-to-value ratio (LTV). Guerrieri and Lorenzoni (2011) explore changes in both these dimensions in a theoretical model with

\footnotetext{
${ }^{2}$ The literature indicates that this type of policy action indeed affects the mortgage spread. See Fuster and Willen (2010), Hancock and Passmore (2011) and Krishnamurthy and Vissing-Jorgensen (2011).
} 
heterogeneous agents. An important finding in their model is that changes in the LTV ratio only mildly affect the aggregate variables while spread changes have a major impact.

The present paper also complements the literature addressing other non-price aspects of mortgage supply. Wilcox (2009) and Muellbauer and Williams (2011) empirically attempt to capture all non-price aspects of mortgage conditions using a latent variable approach.

Kydland et al. (2012) build a theoretical model showing that the cyclical properties of mortgage rates can explain the fact that residential investment leads business investment in the US. The same mechanism explains why housing starts lead business investment both in the US and in other OECD countries. In their model, the mortgage rate enters through the first order condition for residential investment.

The literature examining the macroeconomic effects of the Federal Reserve purchases of MBS is very thin. Chung et al. (2011) provide an estimate of the joint effect of all Large-Scale Asset Purchase (LSAP) programs by using the FRB/US model. Gambacorta et al. (2012) take a broader approach and estimate the effect of the size of central bank balance sheets on aggregate variables in a cross-country SVAR study. Gertler and Karadi (2013a) provide a model of how LSAPs affect the macroeconomy. They model LSAPs as a form of financial intermediation and find that central bank purchases of private assets (corporate bonds) are more powerful than purchases of long-term government debt. For a model of LSAPs that distinguishes between corporate debt and mortgage debt, see Dai et al. (2013).

The analogous literature addressing corporate interest rate spreads and how shocks to these affect business investment and the business cycle more generally is well developed. For structural VAR approaches, see, for example, Gertler and Lown (1999), Gilchrist et al. (2009), Gilchrist and Zakrajšek (2012), Meeks (2012) and Furlanetto et al. (2013). Helbling et al. (2011) considers international transmission of this type of shocks. Two examples of estimated DSGE models that allow for financial shocks and use corporate spread data are Christiano et al. (2011) and Christiano et al. (2014). Jermann and Quadrini (2012) and Nolan and Thoenissen (2009) also show the importance of shocks to firm financing by taking models to the data, but do not specifically include spread data. Fornari and Stracca (2013) apply a structural VAR approach without spreads that instead uses sign restrictions for identification of financial shocks. More generally, the business cycle literature appears to be relaxing the previously prevalent assumption that one interest rate is sufficient to characterize the economy.

\section{Data}

This section documents the countries and sample periods used. In addition, the measurement of the mortgage spread is described and the spread is characterized.

Our main country of study is the US. The sample period is 1983q1-2011q4. The sample begins in 1983 in order to avoid the Regulation Q and the Volcker disinflation periods. The UK and Sweden are also studied. These two countries provide an 
international perspective and contrast the US in that mortgage contracts have a much shorter duration. Data availability and active mortgage markets also make these countries useful comparisons. For the UK and Sweden, the sample begins in 1995q1, when both countries started to systematically collect data on mortgage rates. Data availability for aggregate quantities dictates that the frequency is quarterly.

\subsection{Mortgage spread definition and characteristics}

The mortgage rate and spread are measured in terms of the cross-sectional average. The ideal measure of this spread would be one based on a mortgage rate that has a fixed composition in terms of the LTV ratio, and the type of borrower and lender, and is representative of all mortgages. Clearly, this ideal measure is unobtainable.

For economic and measurement reasons, we work with the rates of newly issued mortgages as opposed to the stock of outstanding mortgages. Economically, the newly issued mortgages contain the new information about mortgage pricing. They are also the relevant rates for house buyers. From a measurement perspective, the maturity of newly issued mortgages is well-defined, while the maturity of the stock of outstanding mortgages is more difficult to measure and has an additional time-varying element.

The mortgage rate data used is from surveys of quoted rates. Abstracting from a constant difference in levels, these correspond well with transaction based data. ${ }^{3}$ The residential mortgage rates obtained are for a given maturity and the spread is computed against the government bond with the corresponding maturity. The mortgage rate data used is for conventional conforming mortgages in the Primary Mortgage Market Survey from Freddie Mac. ${ }^{4}$

The surveys specify a LTV ratio of 80 percent for the US and a LTV ratio of 75 percent for the UK. The 30-year fixed rate is used for the US and the 2-year fixed rate is used for the UK and Sweden. See the Data Appendix for details on the fraction of mortgages at various maturities that motivated this choice. The US is the only country in our sample with non-negligible mortgage pre-payment activity. Accordingly, the other countries' mortgage rates are matched with a government bond of the same maturity (de jure, face value). For the US, the conventional estimate is that the duration of a 30-year fixed rate mortgage is 7-8 years. Accordingly, our baseline specification assumes a mortgage duration of 7.5 years. In a robustness exercise, we try to capture the time variation in the expected duration (and the value of the prepayment option) of 30-year fixed rate mortgages.

The US mortgage spread is plotted in Figure 1. To highlight the cyclicality, the National Bureau of Economic Research (NBER) recession dates and the Congressional Budget Office (CBO) GDP gap are illustrated in the same figure. The substantial variation as well as the countercyclicality of the spread are evident.

Key moments of the mortgage spread are documented in Table $1 .^{5}$ The table

\footnotetext{
${ }^{3}$ Transaction based mortgage rates for narrow maturities are only available for the latter part of the sample period.

${ }^{4}$ We use mortgage rates at face value and abstract from "points" in the Primary Mortgage Market Survey as the points were not measured for the full sample and changed definition in 1998.

${ }^{5}$ Results for GDP deviation from CBO potential GDP are very similar to the deviation
} 
shows that mortgage spreads are reasonably volatile and countercyclical. ${ }^{6}$ In particular, they lead the business cycle by $2-3$ quarters. ${ }^{7}$ The US mortgage spread variation is driven in equal parts by the variation in the mortgage rate and the government bond rate at the quarterly frequency. There is no apparent lagging tendency in the mortgage rate compared to the Treasury bond rate. There are cross-country differences in mortgage spread characteristics, but the similarities dominate. In summary, the cyclical characteristics of mortgage spreads encourage us to explore their structural role for the business cycle.

The lower part of Table 1 documents the relationship between mortgage spreads and corporate spreads. Mortgage spreads ("mspreads") are less volatile than corporate spreads ("cspreads") and the two series are highly correlated.

\section{Mortgage spread innovations and business cy- cles}

This section documents this paper's main quantitative exercises and results. The aim is to quantify the effects of innovations to the mortgage spread on the rest of the economy. We do this by estimating a structural VAR.

\subsection{Structural VAR specification}

Based on which aggregate variables could plausibly be affected by (or affect) the mortgage spread, the VAR includes the following variables: consumption, residential investment, GDP, the consumer price level, the mortgage spread, the (nominal) policy interest rate and house prices. All quantities and house prices are in real terms. Where appropriate, variables are expressed in natural logs. We estimate the VAR in levels. Recall that the frequency of the data is quarterly.

The identifying restriction is that mortgage spread shocks do not affect aggregate quantities or consumer prices on impact, but they are allowed to contemporaneously (within the quarter) affect the policy rate and house prices. ${ }^{8}$ Alternative identifying restrictions are explored in the robustness section. A secondary exercise documents monetary policy shocks mainly as a point of comparison but also to document the role of the mortgage spread in the monetary transmission mechanism. Monetary policy

from Hodrick-Prescott trend. In particular, Corr $(\operatorname{mspread}, \mathrm{GDP})=-0.34$ and the maximum crosscorrelation is $\operatorname{corr}\left(\operatorname{mspread}_{t+3}, \mathrm{GDP}_{t}\right)=-0.42$.

${ }^{6}$ Time variation in the composition of borrowers, and, in particular, stricter requirements/screening in downturns, would make the mortgage spread lower in these periods, i.e. less countercyclical. In other words, the true countercyclicality of mortgage spreads is probably stronger than the measured one.

${ }^{7}$ For a more detailed documentation of the cyclical pattern of mortgage spreads in the US, see Table B.16 in the Appendix.

${ }^{8}$ With regard to the information lag, the Freddie Mac mortgage rate survey (PMMS) is collected and disseminated very quickly. The survey is performed weekly and published with at most a three day delay. This makes it reasonable to assume that the mortgage spread can be incorporated in the monetary policy decision within the quarter. 
shocks are only allowed to affect house prices contemporaneously. We do not identify any other shocks beyond these two and, accordingly, the ordering between the other variables does not matter.

Lag length selection is generally difficult in this type of exercise. Robustness of the results to reasonable variation in lag length is therefore documented. We use four lags for the US but two lags for the UK and Sweden because of their shorter sample period. All data series used as well as statistical properties of our specification are provided in the Statistical Appendix.

The VAR is estimated using a Bayesian approach with flat priors.

\subsection{Time series of mortgage spread innovations}

The US mortgage spread innovations are plotted in Figure 2 to provide indicative validation. Extreme innovations have been marked in the figure: 1984q2(-), 1986q3(+), 1990q3(-) (the beginning of Gulf War I), 1998q4(+) (following the LTCM bailout and the Russian financial crisis) and 2008q1(+) (the US housing crisis). ${ }^{9}$

The largest policy intervention in the mortgage market is the November 25th, 2008 announcement of the Federal Reserve's "QE1/LSAP1" program, which consisted of buying $\$ 500$ billion (extended in March 2009 to $\$ 1.25$ trillion) of MBS from January 2009 to March 2010. The first three quarters following this announcement are marked in bold red in Figure 2. All three quarters are characterized by negative innovations. This suggests the joint hypothesis that i) the SVAR is correctly capturing innovations to the mortgage spread and ii) that the Federal Reserve's MBS purchase program had a substantial effect on mortgage spreads.

A negative one standard deviation innovation implies a 18 bps decrease in the mortgage spread on impact. For the following quarter, the effect is 12 bps and for the third quarter, $7 \mathrm{bps}$. Accordingly, the innovations in the three quarters 2008q4$2009 q 2(-0.3,-1.1$ and -1.0 standard deviations) add up to a peak effect of 33 bps. This contrasts with Hancock and Passmore (2011) who find a 100-150 bps effect using a very different method. However, our results are similar to the event-study results of Fuster and Willen (2010). ${ }^{10}$ The VAR method only yields total innovations. Therefore, the comparison is halting as it assumes that no other unexpected events affected mortgage spreads during these three quarters. For this reason, the results in Figure 2 for 2008q4-2009q2 are mainly an indicative validation of the SVAR specification, rather than providing insight regarding the quantitative effect on the mortgage spread of the MBS purchase program, QE1. For the macroeconomic effects of QE1, see section 3.3.1 below.

\footnotetext{
${ }^{9}$ Neither the 1992 ERM crisis in Europe nor the 1997 Asian financial crisis coincide with any extreme innovations to the mortgage spread. However, the mortgage spread was hit by innovations amounting to a total of three standard deviations in the three quarters of the ERM crisis, 1992q3$1993 q 1$.

${ }^{10}$ The time profile of the effects differ between our results and the literature, e.g. Hancock and Passmore (2011) find the majority of the effect already in 2008q4. One important reason that we do not obtain such a fast effect is that we use average mortgage rates per quarter, which limits the Q4 impact of a policy action announced on November 25th.
} 


\subsection{Dynamic effects of mortgage spread innovations}

Figure 3 documents the US impulse response functions for a mortgage spread innovation. All IRF plots include 68 percent and 90 percent probability intervals in addition to the median response. If not otherwise noted, all numbers reported in the text refer to the median estimate. The mortgage spread shock yields a gradual contraction in all aggregate quantities and a fall in the policy rate and house prices. Consumer prices is the only variable that does not respond. This qualitative characterization is consistent with our hypothesis that mortgage spread innovations should be interpreted as credit supply shocks.

In terms of magnitudes, a one standard deviation (18 bps) shock to the mortgage spread results in a decline in consumption of 0.3 percent, in residential investment of 1.1 percent, in GDP of 0.4 percent and in house prices of 0.5 percent. Furthermore, the federal funds rate declines by 33 bps thereby dampening the response of other variables. One interpretation of the strong policy response is that policy makers are well aware of the contractionary effects of mortgage shocks in spite of the absence of academic literature. The largest effect on the aggregate quantities occurs after five quarters, while the federal funds rate and house prices react more quickly. The entire 90 percent probability band of the responses is below zero for all these variables in some quarters, with the exception of residential investment.

To facilitate interpretation and comparison, we document the amplitude of the response of key variables to a unit-sized shock. These "elasticities" to the mortgage spread shock are displayed in the first column of Table $2 .{ }^{11}$ The interpretation is, for example, that a 100 bps shock to the mortgage spread reduces GDP by 1.9 percent and house prices by 2.6 percent. Consumption responds slightly less than GDP while residential investment responds three times more. The policy rate responds strongly, falling 184 bps. Note that it is difficult to compare changes in interest rates at such different maturities. The comparison is clouded by the fact that the mortgage rate of a contract signed in the quarter of the shock stays fixed (in expectation) for 7.5 years while a federal funds contract is overnight. Table A.5 documents the uncertainty of the estimation in terms of 68 percent and 90 percent probability bands for the elasticities. These bands are reasonably tight, with the exception of residential investment. For example, for all variables, the elasticity to a mortgage shock is below -1 with 84 percent probability.

The IRF to a monetary policy shock is documented in Figure 4. The message we want to convey with this IRF is twofold. First, the effects on macro variables are qualitatively similar to those of the mortgage shock, though more delayed. Second, there is no clear effect from the monetary policy shock on the mortgage spread (note the small scale on the mortgage spread response). ${ }^{12,13}$ The second statement

\footnotetext{
${ }^{11}$ When computing the amplitude, we only consider the first 12 quarters of the IRF to avoid being mislead by oscillations or extreme longer run dynamics.

${ }^{12}$ This result is robust to letting the monetary policy shock affect the mortgage spread contemporaneously. Details are documented in section A.5.1.

${ }^{13}$ The effect of monetary policy shocks on mortgage spreads are explored also in Gertler and Karadi (2013b) and Gilchrist et al. (2013). Both of these papers use high-frequency data to identify
} 
implies that there are no signs of either i) amplification of the monetary transmission through the mortgage spread, or ii) deceleration due to imperfect or delayed passthrough from monetary policy to mortgage rates. The former contradicts the "balance sheet channel" theory applied to housing and mortgages whereby the monetary policy shock reduces the collateral values of borrowers and therefore increase spreads. The latter contradicts the limited pass-through to lending rates as reported in, for example, Kobayashi (2008). While unlikely, it could be that both these mechanisms are important but that they cancel each other out.

Table 3 documents the fraction of the variance that is attributed to the mortgage spread shock for key variables. Between two-thirds (2 quarter horizon) and one-third (16 quarters horizon) of the variation in the mortgage spread is due to the mortgage shock itself. The importance of the mortgage spread shock for aggregate quantities is generally moderate. Its importance is highest for consumption and GDP at the 8 quarter horizon, at or above 10 percent. The policy rate is the variable most affected by the mortgage spread shock: one quarter of its variation at short horizons is driven by this type shock. Finally, roughly 10 percent of house price variation is due to the spread shock at the 2-4 quarters horizon, but less than 10 percent for longer horizons. Comparing the variance decomposition results to the existing literature, the mortgage spread shock is as important as the corporate excess bond premium shock documented in Gilchrist and Zakrajšek (2012) in terms of consumption and GDP, and substantially more important for the policy rate. ${ }^{14}$

Historical decomposition for the mortgage spread shock is documented in Figure 5. In line with the variance decomposition, we note the moderate importance of the mortgage shock. Figure 5 indicates that in the 2004-2007 run-up to the crisis, without mortgage shocks mortgage spreads would have been higher while GDP and the federal funds rate would have been lower. Conversely, in the absence of mortgage shocks, GDP would have stayed higher in the 2008-2009 downturn. A similar tendency is present in house prices, but quantitatively, the spread shock appears to have had a negligible effect on the house price boom-bust. ${ }^{15}$ Recall that our analysis does not explicitly include subprime lending conditions, which plausibly was an important driver of house prices in this time period. To summarize, mortgage spread shocks had a destabilizing effect during the most recent business cycle.

\subsubsection{Zero lower bound dynamics and the macroeconomic effects of QE1}

The purpose of this subsection is twofold. First, we characterize the effects of a mortgage spread innovation when the federal funds rate is held fixed. Second, we use these results to quantify the macroeconomic effects of QE1.

monetary policy shocks. The former paper obtains mortgage spread dynamics that amplify monetary policy shocks, while the latter paper obtains results in line with ours.

${ }^{14}$ Gilchrist and Zakrajšek (2012) find that the excess (corporate) bond premium shock explains roughly $10 \%$ of consumption, $25 \%$ of business investment, and slightly more than $10 \%$ of GDP.

${ }^{15}$ The historical decomposition results for the UK and Sweden are very similar to the US results, and are reported in Appendix A.3. The only notable difference is that in those countries, the mortgage spread shock was more important for house prices. 
Impulse responses for a situation with a fixed federal funds rate are generated using the method in Sims and Zha (2006). This implies setting all coefficients for the federal funds rate equal to zero in the VAR. Unsurprisingly, the impulse responses documented in Figure 6 have greater amplitude than the impulses in our baseline specification. The maximum effects are obtained more slowly compared to the baseline specification. The elasticities are documented in the second column of Table 2 and are substantially greater for all variables. The difference is most pronounced for residential investment and house prices where elasticities are more than twice as large when the policy interest rate is held fixed. ${ }^{16}$

The elasticities from the above counterfactual exercise are used to compute the effects of the unconventional monetary policy known as QE1. This implies assuming that the federal funds rate is held fixed across all horizons. Admittedly, this is merely an approximate way to handle the zero lower bound (ZLB). At some horizon, the ZLB will no longer bind and this is abstracted from.

As previously mentioned, the size of the mortgage spread innovation generated by QE1 is unclear. Our estimates are $(-0.3,-1.1$ and -1.0$)$ for $2008 \mathrm{q} 4-2009 \mathrm{q} 2$, corresponding to a peak effect on mortgages spreads of 33 bps and a total of 2.4 standard deviations. ${ }^{17}$ We also present results for Hancock and Passmore's (2011) upper-end estimate of 150 bps (10.9 standard deviations). Table 4 documents both cases. Effects are large on the two housing variables and substantial for consumption and GDP particularly for Hancock and Passmore's upper-end estimate of the unconventional policy effect on spreads.

\subsection{Comparison of results to the previous literature}

There is one empirical paper with which we can compare our mortgage spread shock results: Musso et al. (2011, MNS) perform a related SVAR analysis. Their VAR specification contains the following variables, where the ordering reflects identifying assumptions on impact restrictions: consumer prices, consumption, residential investment, house prices, 3-month interbank rate, (30-year fixed) mortgage lending rate and nominal mortgage debt. MNS find a much smaller role for mortgage related shocks than we do. Their estimated IRFs indicate very weak responses in the short run. Residential investment is the only variable where the 68 percent probability band does not include zero for the first 10 quarters. Furthermore, MNS obtain a negligible response of the policy rate to a mortgage rate shock. Finally, in terms of a long horizon (24 quarters) variance decomposition, their mortgage rate shock plays no role, i.e. it explains less than 1.5 percent of any variable except the mortgage rate itself. $^{18}$

\footnotetext{
${ }^{16}$ As noted previously, we only consider the first 12 quarters when computing elasticities. This implies that we abstract from the longer horizon decline in house prices for this specification.

${ }^{17}$ Given the persistent effect on these variables, the peak effects are well approximated by multiplying the effect of one standard deviation by the sum of the innovations which amounts to 2.4. Recall that we use a linear method, such that the size of the effect scales linearly in the size of the innovation.

${ }^{18}$ MNS's results for the Euro area (EA) are very different from their US results in terms of variance decomposition. For EA, MNS find a substantial $(>10 \%)$ role for mortgage shocks for residential
} 
What explains the difference in results between the present paper and MNS? Two alternatives appear plausible ex ante: differences in the recursive ordering of variables or that MNS use a mortgage rate rather than a mortgage spread. As documented in section A.5.1, our results are robust to reordering of variables. Here, we show that the differences are instead due to the choice of variable: mortgage rate vs. mortgage spread.

This is done by estimating a variation of our baseline VAR with a mortgage rate instead of a mortgage spread. In other words, the VAR specification is changed in the direction of MNS but only in this one dimension. Figure 7 documents the IRFs. They are qualitatively similar to MNS (their Figure 7, the "Lending rate shock" panel). That is, consumption and house prices do not respond substantially, residential investment decreases and the federal funds rate increases in the short term. The consumer price level decreases after a couple of years. The only notable difference vs. the result in MNS is that the federal funds rate increases substantially more in our VAR. This is because the variables are ordered differently (see section A.5.1 for details). We maintain that our ordering is the economically reasonable one in that policy makers can observe the mortgage rate within the quarter and therefore can react to it contemporaneously. We conclude that all other differences in results vs. MNS are due to the presence of the mortgage spread instead of the mortgage rate in the VAR specification.

It is preferable to use a mortgage spread rather than a mortgage rate because it allows a mortgage-specific variable to be isolated so as to extract mortgage-specific shocks. A long-duration mortgage rate consists of three components: a short-term risk-free rate, a term spread and a mortgage spread. These components all have different effects on the business cycle, both theoretically and empirically. It is therefore detrimental to mix them up.

Our results can also be compared to those obtained in theoretical models. This exercise is somewhat clouded by comparison problems related to non-linearities in these models and discrepancies between the empirically relevant 30-year fixed rate mortgage (with a prepayment option) and the debt contracts in the models. The most appropriate comparison is to an exercise in Guerrieri and Lorenzoni (2011). They analyze a large temporary shock to intermediation cost (spreads) in a model with durable and non-durable consumption abstracting from the ZLB. In terms of 7.5-year duration mortgage rates, they find an output elasticity of 7.0 which is substantially larger than our estimated elasticity of $1.9 .{ }^{19}$ When they include the ZLB, they instead find an output elasticity of 19.4 compared to our ZLB estimate of 2.4. An important reason for why Guerrieri and Lorenzoni (2011) obtain an immediate and large effect on output is their assumption that all loan contracts are one-period, implicitly an adjustable interest rate assumption.

\footnotetext{
investment, total mortgage debt outstanding and the 3-month interbank rate.

${ }^{19}$ The shock modeled increases the spread by $6 \%$ in annualized terms for the first quarter and then decaying by a factor 0.6. Averaging the impact over 7.5 years (30 quarters) of $0.06^{*} 0.6^{\wedge}(\mathrm{t}-1)$ yields 50 basis points on the fixed rate mortgage. It is then trivial to compute the elasticity of output.
} 


\subsection{International perspective - UK and Sweden}

The VAR is also estimated for the UK and Sweden. The same qualitative results are obtained as for the US: mortgage spread innovations are both statistically and economically important. Furthermore, positive mortgage spread innovations induce contractionary dynamics in line with their interpretation as credit supply shocks. The results are also quantitatively broadly similar. There are, however, some interesting cross-country differences. Most notably, consumption and GDP react faster to mortgage spread shocks in both the UK and Sweden. A plausible reason for this difference is that both countries have a low average duration of mortgages (and a high fraction of adjustable rate mortgages). Two other key differences are that both consumption and the policy rate respond less in the UK and Sweden. The results and detailed discussion are provided in Appendix A.3.

\section{Robustness}

The VAR specification is altered in the following six ways to document the robustness of the results: i) inclusion of a corporate bond spread, ii) the use of sign and zero restrictions for identification, iii) the use of a spread measure that accounts for the option value of prepaying the mortgage, iv) the change of the ordering of variables so that mortgage shocks are allowed to affect fewer variables contemporaneously, v) the sample period is shortened to 1983q1-2008q2, and vi) the lag length is varied. The first three of the robustness exercises are documented in the body of this paper and last three in Appendix A.5.

In addition, to confirm the interpretation of the mortgage spread shock as a credit supply shock, we estimate an alternative SVAR specification in which the quantity of mortgage debt outstanding is added to the baseline VAR.

\subsection{Including a corporate bond spread}

As already noted in section 2.1, Table 1, mortgage spreads and corporate bond spreads are highly correlated and have a correlation coefficient of 0.83 . Their relationship is further documented in Figure C.20. The high degree of comovement motivates an alternative specification to ensure that a causal effect from mortgage spreads to aggregate quantities and house prices is captured. A corporate spread is added to the VAR and is ordered before the mortgage spread. This implies that common contemporaneous variation in the two spreads that is orthogonal to contemporaneous movements in aggregate quantities and consumer prices will be labeled a corporate spread shock. Only the remaining variation in mortgage spreads that is orthogonal to contemporaneous movements in aggregate quantities and inflation will be filtered out as mortgage spread innovations.

Visually, the IRFs reported in Figure 8 are similar to the baseline specification except that some probability bands are wider and some magnitudes are marginally larger. Compared to the baseline specification, the standard deviation of the mortgage spread shock is marginally reduced from 18 bps to 16 bps. The mortgage shock 
elasticities are reported in the third column of Table 2. Interestingly, they are slightly higher than those for the baseline specification. The same tendency is present for the variance decomposition (not reported) in that there is a larger role for the mortgage spread shock than in our baseline specification. Finally, the mortgage spread shock is generally substantially more important than the corporate spread shock in terms of variance decomposition (not reported), in particular for GDP.

This exercise controls for the comovement between the two spreads as well as possible. We interpret the results as strong, indicative evidence of a causal role of mortgage spread innovations for aggregate variables at business cycle frequencies.

\subsection{Identification through sign and zero restrictions}

In another type of robustness exercise, sign and zero restrictions are used as an alternative identification scheme while retaining the same reduced form VAR. This approach has its limitations, as documented and discussed in Castelnuovo (2013) and Fry and Pagan (2011). ${ }^{20}$ The identification assumptions used are in the same spirit as in Uhlig's (2005) work on monetary policy shocks. The sign restrictions are imposed for the first two quarters of the IRF. The sign restrictions enable us to take a stronger stand on the type of mortgage shock than in the recursive identification; we restrict attention to mortgage supply shocks. This is achieved by imposing that house prices move in the opposite direction as the mortgage spread. We also require that the policy rate change with the opposite sign as the mortgage spread. This is to avoid including a monetary policy shock in the mortgage shock definition. Finally, we require that the mortgage supply shock have no permanent effect on the level of the aggregate quantities. This is to avoid including a permanent productivity shock in the definition of the mortgage shock. One weakness of this identification scheme is that it does not entirely rule out aggregate demand shocks. The identifying assumptions are summarized in Table A.10.

Arias et al. (2013) provide an algorithm that imposes sign restrictions in combination with zero restrictions. That algorithm is used here. ${ }^{21}$ Throughout this section, the median results based on 50,000 draws are reported.

The mortgage supply IRF is documented in Figure 9. Qualitatively, the similarities with the IRF obtained using our baseline recursive identification is striking both in terms of signs and timing. All aggregate quantities decline and reach their trough after slightly more than one year. The shape of the response for the mortgage spread, the federal funds rate and house prices are also similar to those obtained in the baseline specification.

One important difference is that the standard deviation of this shock, roughly 4 bps, is substantially smaller than in the baseline specification. The precision of the IRFs are substantially lower than in the baseline specification, such that the

\footnotetext{
${ }^{20}$ Castelnuovo (2013) shows through Monte Carlo simulations that sign restrictions do not work well in identification of shocks that explain a small fraction of the variance of the observed variables. This critique applies to mortgage spread shocks.

${ }^{21}$ Arias et al. (2013) document severe problems of the dominant algorithm in the sign restriction literature, i.e. the penalty function algorithm in Mountford and Uhlig (2009).
} 
68 percent probability intervals overlap with zero at all horizons for the aggregate quantities. The very marginal exception being for GDP. The low precision in the estimates is a well known general tendency when using sign restrictions.

The elasticities for this specification are documented in the fourth column of Table 2. They are substantially higher than the baseline results by a factor of 2 to 3 .

In terms of the variance contribution of the mortgage shock documented in Table A.11, results are quite similar to those obtained using the baseline specification. The only major differences are the lower contribution to variance of the policy rate and the mortgage spread itself.

To summarize our sign and zero restriction identification exercise, the results are broadly similar to the baseline identification that only imposes zero restrictions on impact. There are three main differences: i) a lower standard deviation of the mortgage spread shock, ii) higher elasticities for the effects on other variables, iii) all estimates are considerably less precise.

\subsection{Option-adjusted spread}

The final robustness exercise aims to control for time variation in the value of the prepayment option in 30-year fixed rate mortgages. This specification measures the mortgage spread using the option-adjusted spread (OAS) from Barclays which is plotted in Figure C.20. This measure is computed as the yield on current coupon agency MBS over and above the corresponding Treasury yield, where the value of the prepayment option has been accounted for. In other words, it is the prepaymentadjusted value of the primary spread (MBS - T-bond yield). The sample begins in $1993 q 4$ due to data availability.

The IRF for this specification is reported in Figure 10. Qualitatively, it coincides with the IRF from the baseline specification, except that the federal funds rate increases in the short run. Key differences are that the mortgage spread shock is less persistent, its volatility is lower (standard deviation 9 bps) and the effects on aggregate quantities peak later, after $3-4$ years. ${ }^{22}$ The precision of the estimates are lower than in the baseline specification, although the entire 90 percent band remains below zero for all quantities and house prices for some quarter. Elasticities are documented in the last column of Table 2 and are substantially higher than in our baseline specification, particularly for residential investment and house prices.

Variance decomposition results (not reported) are roughly the same as in the baseline. The main differences are a larger role of mortgage shocks for residential investment and a smaller role for GDP and the policy rate.

A second OAS-related exercise was performed with the aim to account for both the time variation in the value of the prepayment option and time variation in the secondary spread. The following spread definition was used:

$$
\text { Mspread_pp-adj= } \underbrace{\text { OAS }}_{\text {Primary spread }}+\underbrace{(30 y \text { FRM rate }-30 y \text { MBS yield })}_{\text {Secondary spread }}
$$

\footnotetext{
${ }^{22}$ The amplitude will therefore not be fully captured by our elasticity measure which caps the horizon at 12 quarters.
} 
Results for this specification (not reported) are similar to those in the OAS specification which abstracts from the secondary spread, although elasticities are lower.

\subsection{Mortgage quantities outstanding}

In this VAR specification, the quantity of real mortgage debt outstanding is added to the baseline VAR, ordered last in the system. Impulse responses of three key variables are plotted in Figure A.19. The main finding from this exercise is that mortgage debt decreases in response to a mortgage spread shock, but less so than house prices. The response of mortgage quantities is more delayed and gradual. In terms of precision, the entire 68 percent probability band is only below zero during quarter 5 and 6 . This negative response is a further indication that the mortgage spread shock is a credit supply shock as it increases the price and reduces the quantity of mortgages.

For the UK and Sweden (not plotted), the mortgage spread shock reduces the mortgage debt outstanding for the entire 90 percent probability band. Relative to house prices, this decline is more gradual and long-lasting.

\subsection{Summary of robustness results}

The findings of the robustness exercises are summarized in this section. Several alternative SVAR specifications have been explored. Generally, the alternative specifications attribute a slightly larger role to mortgage innovations for the business cycle than our baseline specification. E.g., we note that any plausible recursive identification (Appendix A.5.1) or an increase in the number of lags (Appendix A.5.3) delivers effects of mortgage spread shocks on the aggregate quantities that are at least as large as in the baseline specification. The specifications with sign restriction identification and the OAS measure yield substantially larger effects in terms of elasticity of aggregate variables to the mortgage shock. The only exercise indicating a smaller role for mortgage spread shocks is when the sample is shortened to exclude the ZLB period and the financial crisis (Appendix A.5.2).

In all estimated specifications, the elasticity of GDP to mortgage shocks are in the $(-0.9,-5.9)$ interval with the subsample specification yielding the lowest elasticity and the sign restriction identification yielding the highest (see Table 2, Table A.12 and Table A.14). The corresponding intervals for consumption are $(-0.8,-4.8)$, for residential investment $(-3.5,-26)$ and for house prices $(-0.8,-13)$.

If we restrict attention to the full sample, the range of elasticities due to VAR specification are $(-1.9,-5,9)$ for GDP, $(-1.6,-4.8)$ for consumption, $(-5.0,-20)$ for residential investment and $(-2.6,-10)$ for house prices. In this comparison, the sign restriction approach consistently yields the highest elasticities.

Differences in variance decomposition are substantially smaller. Accordingly, in a mechanic sense, the differences in elasticities between specifications is predominantly driven by differences in the standard deviation of the mortgage spread shock. 


\section{Interpretation of mortgage shocks and conclu- sions}

We have used a SVAR with aggregate quantities, consumer prices, the mortgage spread, the federal funds rate and house prices to extract exogenous innovations to the mortgage spread. Strong indicative evidence is found that these innovations should be interpreted as credit supply shocks. Nevertheless, it is not obvious what the concrete underlying factors are that generate these innovations. Recall that the baseline identification is set up such that only spread movements that are orthogonal to contemporaneous and lagged aggregate quantities and house prices are picked up as mortgage spread innovations.

Potential underlying drivers are: (i) changes in the degree of competition in the mortgage industry, (ii) changes in banks' balance sheets (leverage) or liquidity, (iii) changes in financial regulation, (iv) changes in financial practices such as the degree of securitization, or, (v) in the most recent years, outright government intervention in the mortgage market such as large purchases of MBS. Finally, (vi) changes in risk aversion or "risk-bearing capacity" of the financial system may generate mortgage spread innovations.

Only a very small fraction of the variation in mortgage spreads can be explained by variation in mortgage default risk. It is therefore a good approximation to consider the time variation in mortgage spreads studied in this paper as an "excess premium" over and above variation in the credit risk in the same spirit as Gilchrist and Zakrajšek (2012) or Meeks (2012). The reason that mortgage credit risk is only marginally affecting spread variation in the US is that more than 75 percent of the prime conforming loans are guaranteed against credit risk by Fannie Mae or Freddie Mac (Fuster et al., 2012). Pricing of these guarantees is not primarily intended to capture macroeconomic variation in credit risk and has very limited $(+/-5$ bps $)$ price variation within our sample period.

The UK and Sweden do not have government sponsored mortgage guarantees. However, credit losses on residential mortgages have been low in these countries and thus variation in credit losses has been limited. The details are documented in the Data Appendix.

Quantitatively distinguishing between the driving factors mentioned above goes beyond the scope of the present paper. Nevertheless, the two exercises using prepayment option-adjusted spreads performed in section 4.3 provide a hint of where to look. The results indicate that it is shocks to the primary mortgage spread rather than shocks to the primary-secondary mortgage spread that affects the macroeconomy.

\subsection{Concluding remarks}

This paper has explored the business cycle effects of innovations to the residential mortgage spread. The approach has been to impose minimum assumptions by estimating a structural VAR instead of a fully specified model. Our main result is that mortgage spread shocks have sizeable effects on the macroeconomy. We have 
confirmed that this result is very robust to variations in the VAR specification, and that they generalize beyond the US to the UK and Sweden. Quantitatively, for our baseline specification, a 100 bps decrease in the mortgage spread yields a 2 percent increase in GDP, or, considering all reasonable VAR specifications and data samples, an increase of between 1 percent and 6 percent.

The takeaways from this paper are the following. First, business cycle fluctuations are affected by financial frictions in the residential mortgage market. Second, innovations in the mortgage spread appear to capture movements in credit supply that are moderately important for business cycle variation in aggregate quantities and house prices. Third, the policy rate partially offsets mortgage spread innovations and its variance is to a substantial degree driven by these innovations. Finally, if unconventional monetary policy succeeds in affecting the mortgage spread, then it has sizable effects on aggregate quantities and house prices. Similarly, macroprudential policies that affect the mortgage spread will have sizable effects on the business cycle.

An interesting avenue for future research is to build a structural model of the interaction between the macroeconomy and the mortgage spread. Ideally, such a model would imply that a substantial part of the mortgage spread variation is endogenous, as indicated by our VAR results. One may view this as an extension of the model in Cúrdia and Woodford (2009) with the added complication of sector-specific spreads. One reason that a structural model would be valuable is that it would enable us to explicitly analyze normative issues. In particular, are mortgage spread shocks inefficient and should they thus be counteracted by monetary policy? In this area, policy practice appear to be ahead of theory.

\section{References}

[1] Arias, J., Rubio-Ramírez, J. and Waggoner, D., 2013. Inference Based on SVARs Identified with Sign and Zero Restrictions: Theory and Applications. FEDEA Working Paper 2013-24.

[2] Castelnuovo, E., 2013. Monetary Policy Neutrality? Sign Restrictions Go to Monte Carlo. Mimeo.

[3] Christiano, L., Motto, R. and Rostagno. M., 2014. Risk Shocks. American Economic Review 104, 27-65.

[4] Christiano, L., Trabandt, M. and Walentin, K., 2011. Introducing Financial Frictions and Unemployment into a Small Open Economy Model. Journal of Economic Dynamics and Control 35, 1999-2041.

[5] Chung, H., Laforte, J., Reifschneider, D. and Williams, J., 2011. Estimating the macroeconomic effects of the Fed's asset purchases. FRB San Francisco Economic Letter.

[6] Cúrdia, V. and Woodford, M., 2009. Credit frictions and optimal monetary policy. Mimeo. 
[7] Darracq Pariès, M., Kok Sørensen, C. and Rodriguez-Palenzuela, D., 2011. Macroeconomic Propagation under Different Regulatory Regimes: Evidence from an Estimated DSGE Model for the Euro Area. International Journal of Central Banking 7, 49-113.

[8] Dai., M., Dufourt, F. and Zhang, Q., 2013. Large Scale Asset Purchases with segmented mortgage and corporate loan markets. Working paper 2013:36, AixMarseille School of Economics.

[9] Fornari, F. and Stracca, L., 2013. What does a financial shock do? First international evidence. ECB working paper 1522.

[10] Fry, R. and Pagan, A., 2011. Sign Restrictions in Structural Vector Autoregressions: A Critical Review. Journal of Economic Literature 49, 938-960.

[11] Furlanetto, F., Ravazzolo, F. and Sarferaz, S., 2013. Identification of financial factors in economic fluctuations. Mimeo.

[12] Fuster, A. and Willen, P., 2010. \$1.25 Trillion is Still Real Money: Some Facts About the Effects of the Federal Reserve's Mortgage Market Investments. FRB of Boston Public Policy Discussion Paper, No. 10-4.

[13] Fuster, A., Goodman, L., Lucca, D., Madar, L., Molloy, L. and Willen, P., 2012 The Rising Gap between Primary and Secondary Mortgage Rate. Mimeo FRB of New York.

[14] Gambacorta, L., Hofmann, B. and Peersman, G., 2012. The Effectiveness of Unconventional Monetary Policy at the Zero Lower Bound: A Cross-Country Analysis. BIS Working Paper 384.

[15] Gerali, A., Neri, S., Sessa, L. and Signoretti, F., 2010. Credit and Banking in a DSGE Model of the Euro Area. Journal of Money, Credit and Banking 42, 107-141.

[16] Gertler, M. and Karadi, P., 2013a. QE 1 vs. 2 vs. 3. . . : A Framework for Analyzing Large-Scale Asset Purchases as a Monetary Policy Tool. International Journal of Central Banking 9, 5-53.

[17] Gertler, M. and Karadi, P., 2013b, Monetary Policy Surprises, Credit Costs and Economic Activity. Mimeo.

[18] Gertler, M. and Lown, C., 1999. The Information in the High-Yield Bond Spread for the Business Cycle: Evidence and Some Implications. Oxford Review of Economic Policy 15, 132-150.

[19] Gilchrist, S., Lopez-Salido, D. and Zakrajšek, E., 2013. Monetary Policy and Real Borrowing Costs at the ZLB. Mimeo. 
[20] Gilchrist, S., Yankov, V. and Zakrajšek, E., 2009. Credit Market Shocks and Economic Fluctuations: Evidence from Corporate Bond and Stock Markets. Journal of Monetary Economics 56, 471-493.

[21] Gilchrist, S. and Zakrajšek, E., 2012. Credit Spreads and Business Cycle Fluctuations. American Economic Review 102, 1692-1720.

[22] Guerrieri, V. and Lorenzoni, G., 2011. Credit Crises, Precautionary Savings. and the Liquidity Trap, NBER working paper 17583.

[23] Hall, R., 2011a. The Long Slump. American Economic Review 101, 431-469.

[24] Hall, R., 2011b. The High Sensitivity of Economic Activity to Financial Frictions. Economic Journal 121, 351-378.

[25] Hancock, D. and Passmore, W., 2011. Did the Federal Reserve's MBS Purchase Program Lower Mortgage Rates? Journal of Monetary Economics 58, 498-514.

[26] Helbling, T., Huidrom, R., Kose, A. and Otrok, C., 2011. Do credit shocks matter? A global perspective. European Economic Review 55, 340-353.

[27] Hubbard, G. and Mayer, C., 2009. The Mortgage Market Meltdown and House Prices, B.E. Journal of Economic Analysis \& Policy 9, Article 8.

[28] Iacoviello, M. and Neri. S., 2010. Housing Market Spillovers: Evidence from an Estimated DSGE Model. American Economic Journal: Macroeconomics 2, 125-164.

[29] Jermann, U. and Quadrini, V., 2012. Macroeconomic Effects of Financial Shocks. American Economic Review 102, 238-271.

[30] Kobayashi, T., 2008. Incomplete Interest Rate Pass-Through and Optimal Monetary Policy. International Journal of Central Banking 4, 77-118.

[31] Krishnamurthy, A. and Vissing-Jorgensen, A., 2011. The Effects of Quantitative Easing on Interest Rates: Channels and Implications for Policy. Brookings Papers on Economic Activity.

[32] Kydland, F., Rupert, P. and Sustek, R., 2012, Housing Dynamics over the Business Cycle. NBER Working Paper 18432.

[33] Meeks, R., 2012. Do credit market shocks drive output fluctuations? Evidence from corporate spreads and defaults. Journal of Economic Dynamics and Control $36,568-584$.

[34] Mountford, A. and Uhlig, H., 2009. What are the Effects of Fiscal Policy Shocks? Journal of Applied Econometrics 24, 960-992.

[35] Muellbauer, J. and Williams, D., 2011. Credit Conditions and the Real Economy: The Elephant in the Room. CEPR Discussion Paper 8386. 
[36] Musso, A., Neri, S. and Stracca, L., 2011. Housing, consumption and monetary policy: How different are the US and the euro area? Journal of Banking \& Finance 35, 3019-3041.

[37] Nolan, C. and Thoenissen, C., 2009. Financial shocks and the U.S. business cycle. Journal of Monetary Economics 56, 596-604.

[38] Sims, C. and Zha, T., 2006. Does Monetary Policy Generate Recessions? Macroeconomic Dynamics 10, 231-272.

[39] Uhlig, H., 2005. What are the effects of monetary policy on output? Results from an agnostic identification procedure. Journal of Monetary Economics 52, 381-419.

[40] Walentin, K., 2013. Housing Collateral and the Monetary Transmission Mechanism. Scandinavian Journal of Economics, forthcoming.

[41] Wilcox, J., 2009. Underwriting, Mortgage Lending, and House Prices: 1996-2008. Business Economics 44, 189-200. 


\section{Tables and Figures}

\begin{tabular}{llll}
\hline \hline Moment $\backslash$ Country & US & UK & Sweden \\
\hline Mean & 1.92 & 1.02 & 1.36 \\
Standard deviation & 0.41 & 0.98 & 0.42 \\
Corr(mspread,GDP) & -0.21 & -0.36 & -0.15 \\
Maximum cross-corr [lead] & $-0.41[3]$ & $-0.43[2]$ & $-0.53[3]$ \\
\hline Standard deviation(cspread) & 0.73 & 1.23 & 0.44 \\
Corr(mspread,cspread) & 0.83 & 0.74 & 0.56 \\
\hline \hline
\end{tabular}

Table 1: Characteristics of the mortgage spread. The third row shows the correlation between the mortgage spread and GDP. The fourth row shows the maximum crosscorrelation and how many quarters ahead of GDP the mortgage spread is for this maximum. The lower part of the table relates the mortgage spread to the corporate spread which is measured as the difference in the interest rates on Moody's Baa-rated corporate bonds and the 10-year Treasury bond. GDP is in terms of deviation from the Hodrick-Prescott trend.

\begin{tabular}{llllll}
\hline \hline Variable & Baseline & Fixed FFR & With corp. spread & Sign restrictions & OAS \\
\hline Consumption & -1.6 & -2.7 & -2.4 & -4.8 & -2.5 \\
Residential investm. & -6.2 & -16 & -6.8 & -20 & -26 \\
GDP & -1.9 & -2.4 & -2.7 & -5.9 & -2.2 \\
Policy rate & -1.8 & $\mathrm{n} / \mathrm{a}$ & -1.8 & -3.4 & 2.6 \\
House prices & -2.6 & -6.9 & -3.2 & -10 & -13 \\
\hline \hline
\end{tabular}

Table 2: Elasticity of variables to mortgage spread shocks. Various VAR specifications. Computed as max (response of variable)/standard deviation of shock. US 1983q1-2011q4, except OAS specification which starts 1993q4. Median. 


\begin{tabular}{llllll}
\hline \hline Variable \Horizon in quarters & 2 & 4 & 8 & 12 & 16 \\
\hline Consumption & 3 & 7 & 9 & 7 & 6 \\
Residential investment & 1 & 3 & 3 & 3 & 3 \\
GDP & 2 & 8 & 14 & 10 & 9 \\
Mortgage spread & 65 & 57 & 43 & 35 & 32 \\
Policy rate & 23 & 20 & 18 & 16 & 14 \\
House prices & 8 & 9 & 4 & 3 & 3 \\
\hline \hline
\end{tabular}

Table 3: Variance decomposition - fraction of variance, in percent, explained by the mortgage spread shock. US 1983q1-2011q4. Median.

\begin{tabular}{lll}
\hline \hline Variable & Our estimate, 33 bps & Upper-end estimate, 150 bps \\
\hline Consumption & 1.2 & 5.4 \\
Residential investment & 6.7 & 30.7 \\
GDP & 1.0 & 4.6 \\
House prices & 3.0 & 13.6 \\
\hline \hline
\end{tabular}

Table 4: Peak effects of QE1 (percentage points).

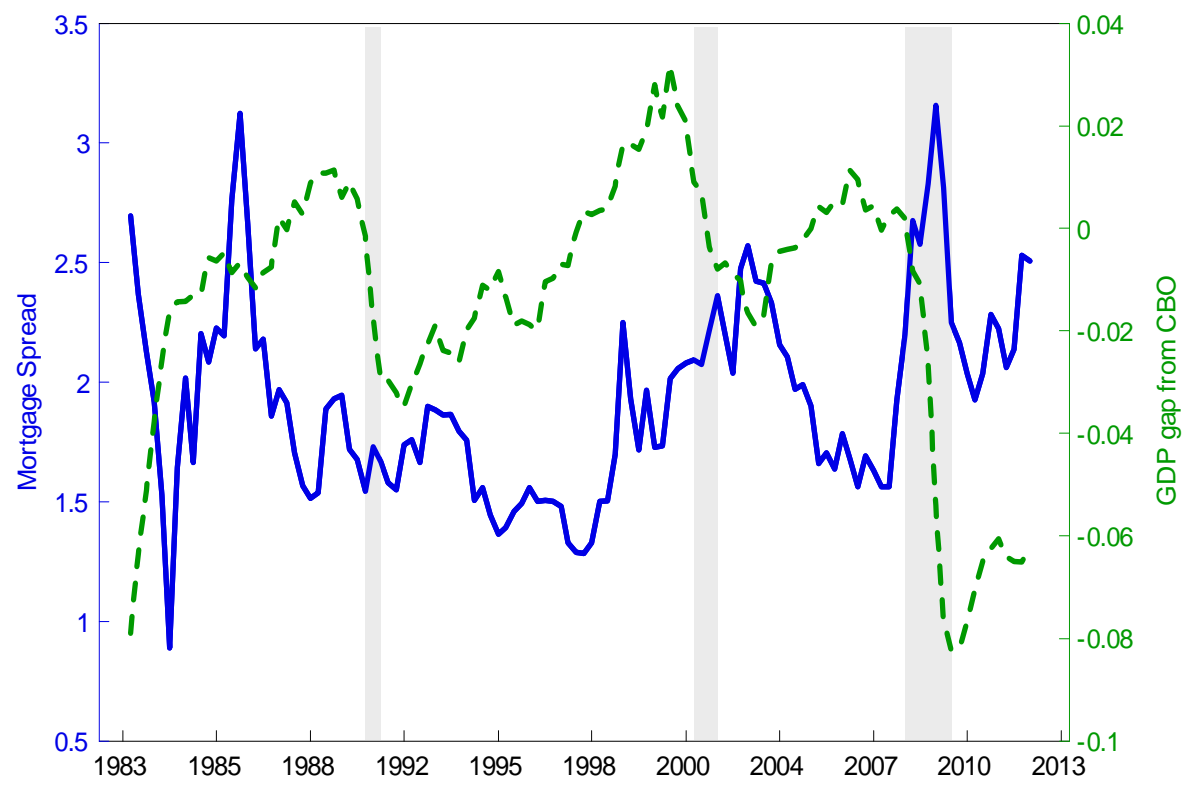

Figure 1. Mortgage spread (solid line), GDP gap (dashed line) based on Congressional Budget Office potential GDP and NBER recession dates (shaded bars). The spread is computed as the 30-year fixed rate mortgage rate minus the average of the 5-year and the 10-year Treasury bond rate. US 1983q1-2011q4. 


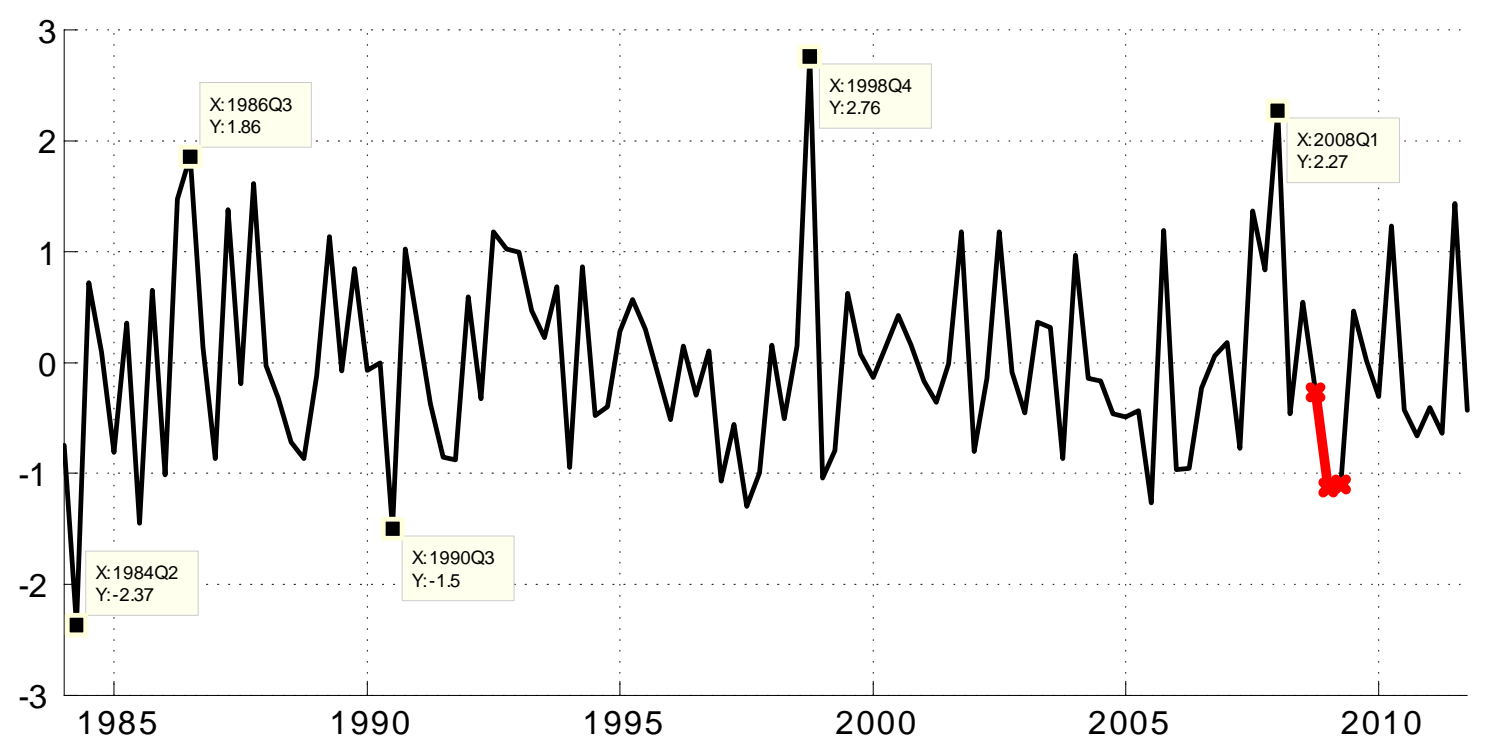

Figure 2. Mortgage spread innovations. US 1983q1-2011q4. Y-axis units are in terms of standard deviations. The standard deviation is 18 basis points. The first three quarters of QE1 are marked in bold red.
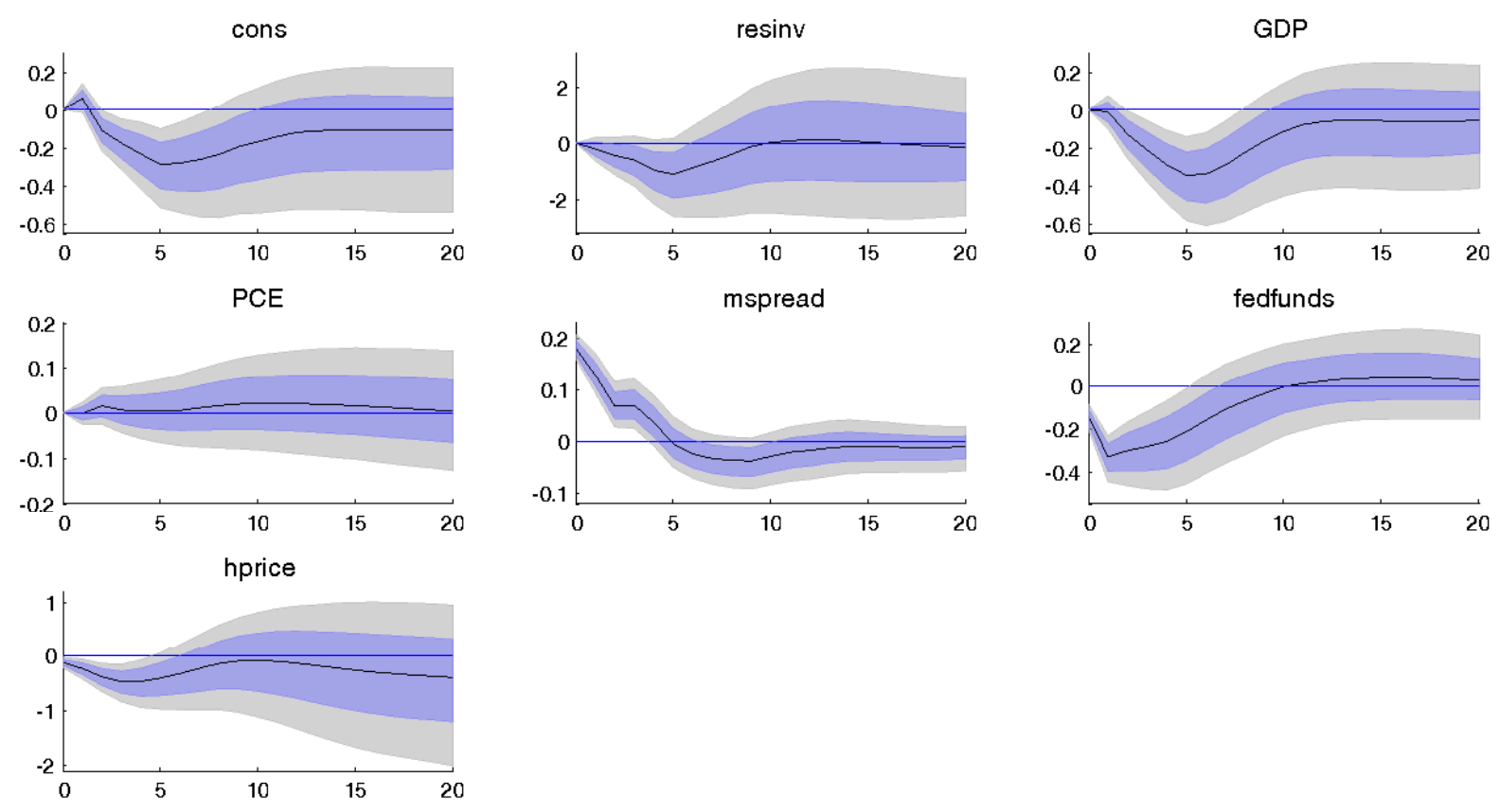

Figure 3. IRF to mortgage spread shock. US 1983q1-2011q4. Units are in percent deviation, except the two interest rates which are in terms of annual percentage rate (APR). Median, 68\% and 90\% probability bands. 

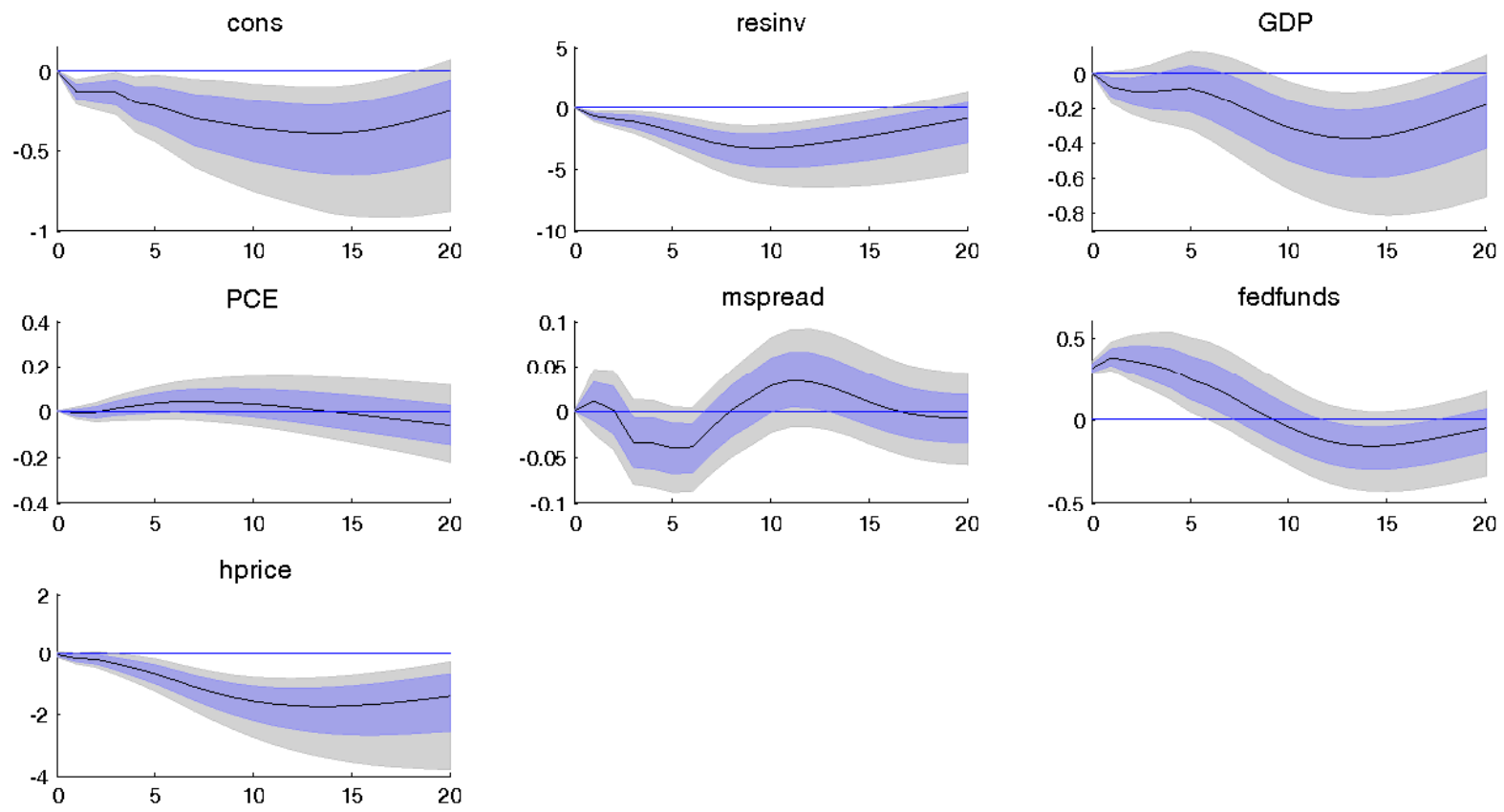

Figure 4. IRF to monetary policy shock. US 1983q1-2011q4. See Figure 3 for units etc.
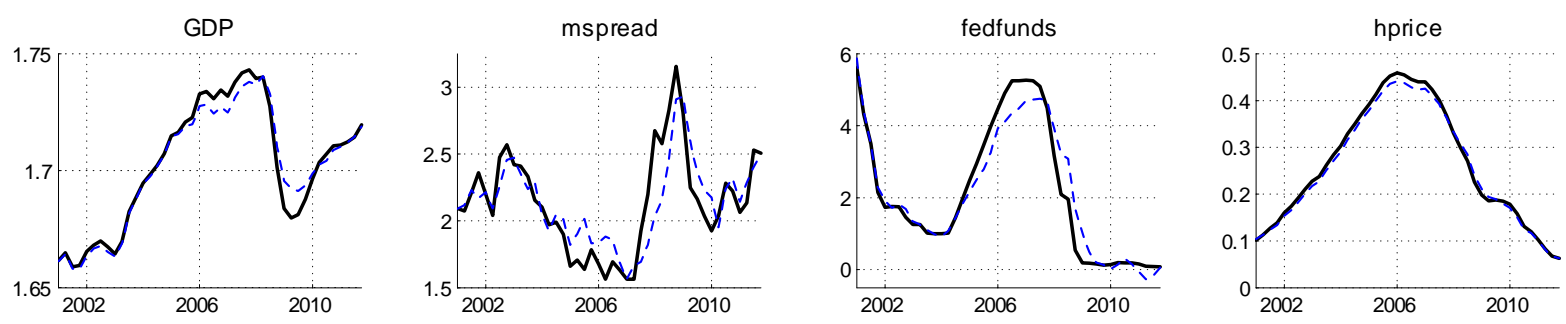

Figure 5. Historical decomposition for US 2001q1-2011q4. Data (solid line) and counterfactual time series where mortgage spread shock is turned off (dashed line). 

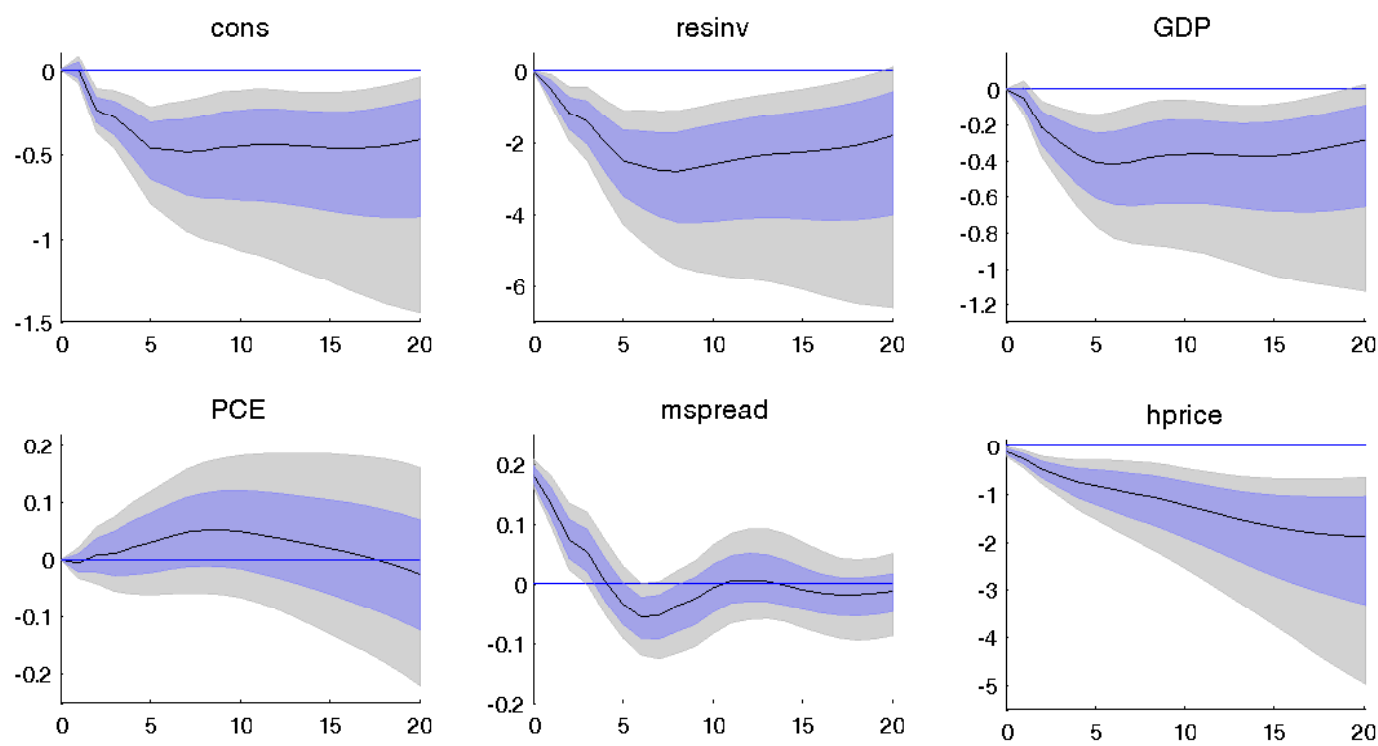

Figure 6. IRF to mortgage spread shock when the federal funds rate is held fixed. US 1983q1-2011q4. See Figure 3 for units etc.
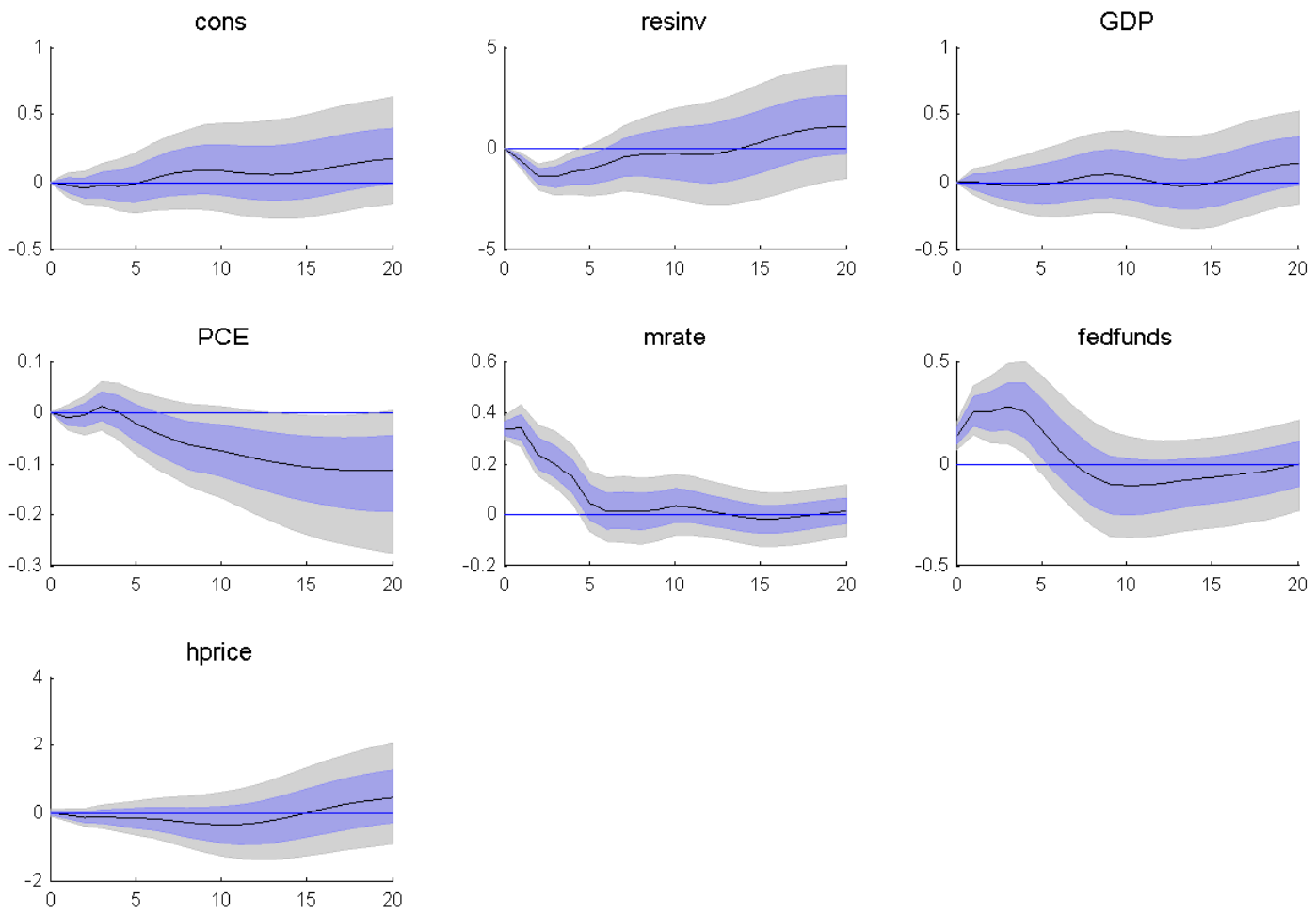

Figure 7. IRF to mortage rate shock. Specification with mortgage rate instead of mortgage spread. US 1983q1-2011q4. See Figure 3 for units etc. 

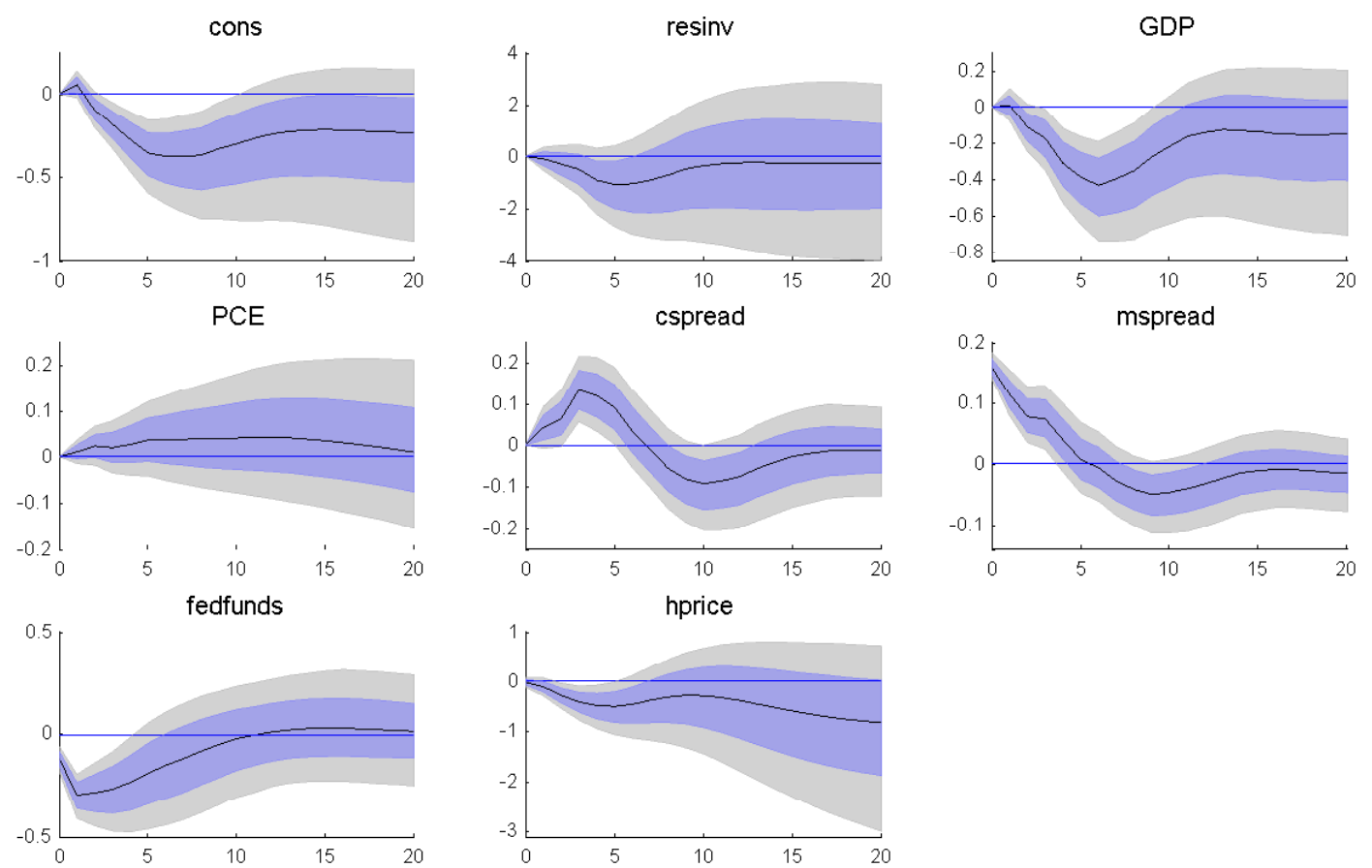

Figure 8. IRF to mortgage spread shock. VAR specification that includes corporate spread. US 1983q1-2011q4. See Figure 3 for units etc.
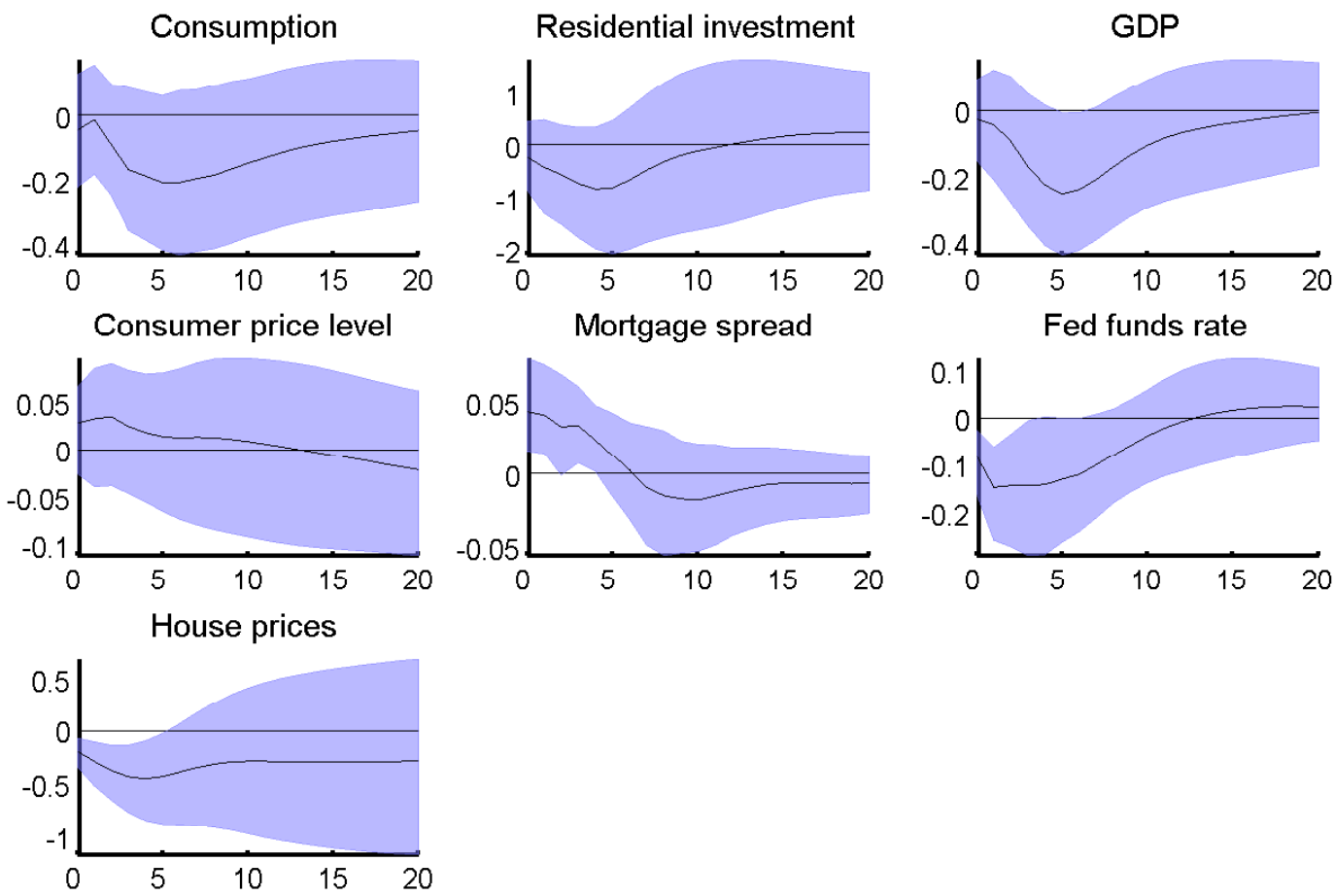

Figure 9. IRF to mortgage spread shock. Identified using sign and zero restrictions.

US 1983q1-2011q4. Median and 68\% probability bands. See Figure 3 for units. 

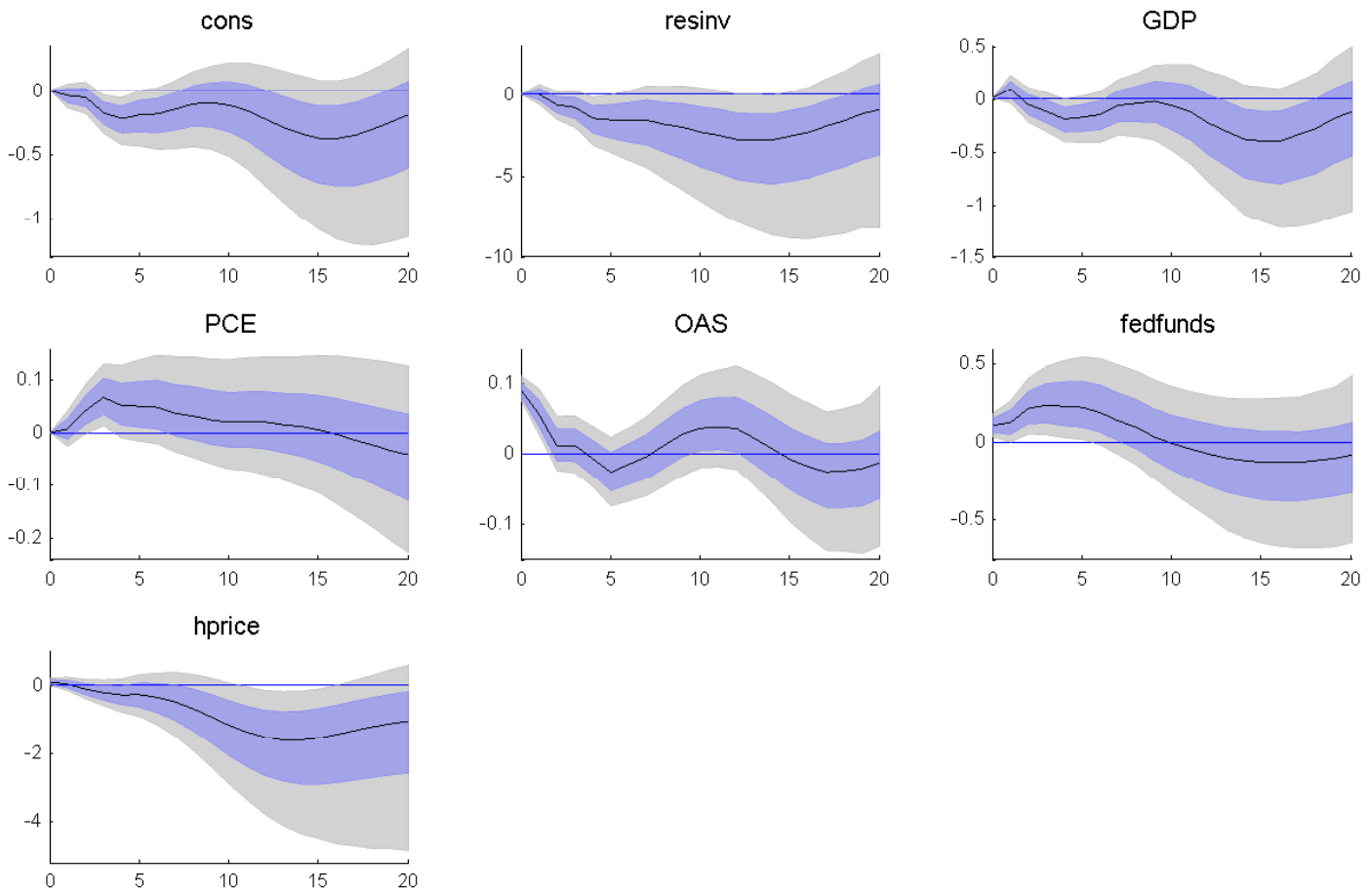

Figure 10. IRF to mortgage spread shock. Specification with option-adjusted spread. US 1993q4-2011q4. See Figure 3 for units etc. 


\section{Earlier Working Papers:}

For a complete list of Working Papers published by Sveriges Riksbank, see www.riksbank.se

Estimation of an Adaptive Stock Market Model with Heterogeneous Agents

2005:177

by Henrik Amilon

Some Further Evidence on Interest-Rate Smoothing: The Role of Measurement Errors in the Output Gap

2005:178

by Mikael Apel and Per Jansson

Bayesian Estimation of an Open Economy DSGE Model with Incomplete Pass-Through

2005:179

by Malin Adolfson, Stefan Laséen, Jesper Lindé and Mattias Villani

Are Constant Interest Rate Forecasts Modest Interventions? Evidence from an Estimated Open Economy

DSGE Model of the Euro Area

by Malin Adolfson, Stefan Laséen, Jesper Lindé and Mattias Villani

Inference in Vector Autoregressive Models with an Informative Prior on the Steady State

by Mattias Villani

Bank Mergers, Competition and Liquidity

by Elena Carletti, Philipp Hartmann and Giancarlo Spagnolo

Testing Near-Rationality using Detailed Survey Data

by Michael F. Bryan and Stefan Palmqvist

Exploring Interactions between Real Activity and the Financial Stance

by Tor Jacobson, Jesper Lindé and Kasper Roszbach

Two-Sided Network Effects, Bank Interchange Fees, and the Allocation of Fixed Costs by Mats A. Bergman

Trade Deficits in the Baltic States: How Long Will the Party Last?

by Rudolfs Bems and Kristian Jönsson

Real Exchange Rate and Consumption Fluctuations follwing Trade Liberalization

by Kristian Jönsson

Modern Forecasting Models in Action: Improving Macroeconomic Analyses at Central Banks

by Malin Adolfson, Michael K. Andersson, Jesper Lindé, Mattias Villani and Anders Vredin

Bayesian Inference of General Linear Restrictions on the Cointegration Space

2005:182

by Mattias Villani

Forecasting Performance of an Open Economy Dynamic Stochastic General Equilibrium Model

by Malin Adolfson, Stefan Laséen, Jesper Lindé and Mattias Villani

Forecast Combination and Model Averaging using Predictive Measures

by Jana Eklund and Sune Karlsson

Swedish Intervention and the Krona Float, 1993-2002

2005:183

by Owen F. Humpage and Javiera Ragnartz

A Simultaneous Model of the Swedish Krona, the US Dollar and the Euro

2005:184

by Hans Lindblad and Peter Sellin

Testing Theories of Job Creation: Does Supply Create Its Own Demand?

2005:185

by Mikael Carlsson, Stefan Eriksson and Nils Gottfries

Down or Out: Assessing The Welfare Costs of Household Investment Mistakes

by Laurent E. Calvet, John Y. Campbell and Paolo Sodini

Efficient Bayesian Inference for Multiple Change-Point and Mixture Innovation Models

by Paolo Giordani and Robert Kohn

Derivation and Estimation of a New Keynesian Phillips Curve in a Small Open Economy

by Karolina Holmberg

Technology Shocks and the Labour-Input Response: Evidence from Firm-Level Data

2005:187

2005:188

by Mikael Carlsson and Jon Smedsaas

Monetary Policy and Staggered Wage Bargaining when Prices are Sticky

by Mikael Carlsson and Andreas Westermark

The Swedish External Position and the Krona

2005:189

$2005: 190$

2005:191

by Philip R. Lane 
Evaluating Microfoundations for Aggregate Price Rigidities: Evidence from Matched Firm-Level Data on

Monetary Policy Trade-Offs in an Estimated Open-Economy DSGE Model

by Malin Adolfson, Stefan Laséen, Jesper Lindé and Lars E. O. Svensson

Flexible Modeling of Conditional Distributions Using Smooth Mixtures of Asymmetric

Student T Densities

by Feng Li, Mattias Villani and Robert Kohn

Forecasting Macroeconomic Time Series with Locally Adaptive Signal Extraction

Risk Premiums and Macroeconomic Dynamics in a Heterogeneous Agent Model

by Ferre De Graeve, Maarten Dossche, Marina Emiris, Henri Sneessens and Raf Wouters

Picking the Brains of MPC Members

by Mikael Apel, Carl Andreas Claussen and Petra Lennartsdotter

Involuntary Unemployment and the Business Cycle

by Lawrence J. Christiano, Mathias Trabandt and Karl Walentin

Housing collateral and the monetary transmission mechanism

by Karl Walentin and Peter Sellin

The Discursive Dilemma in Monetary Policy

by Carl Andreas Claussen and Øistein Røisland

Monetary Regime Change and Business Cycles

by Luca Sala, Ulf Söderström and Antonella Trigari

Density-Conditional Forecasts in Dynamic Multivariate Models by Michael K. Andersson, Stefan Palmqvist and Daniel F. Waggoner

Anticipated Alternative Policy-Rate Paths in Policy Simulations

The Effects of Endogenuos Firm Exit on Business Cycle Dynamics and Optimal Fiscal Policy 


\begin{tabular}{|c|c|}
\hline $\begin{array}{l}\text { The Cost of Consumer Payments in Sweden } \\
\text { by Björn Segendorf and Thomas Jansson }\end{array}$ & $2012: 262$ \\
\hline $\begin{array}{l}\text { Trade Credit and the Propagation of Corporate Failure: An Empirical Analysis } \\
\text { by Tor Jacobson and Erik von Schedvin }\end{array}$ & $2012: 263$ \\
\hline $\begin{array}{l}\text { Structural and Cyclical Forces in the Labor Market During the Great Recession: Cross-Country Evidence } \\
\text { by Luca Sala, Ulf Söderström and AntonellaTrigari }\end{array}$ & $2012: 264$ \\
\hline $\begin{array}{l}\text { Pension Wealth and Household Savings in Europe: Evidence from SHARELIFE } \\
\text { by Rob Alessie, Viola Angelini and Peter van Santen }\end{array}$ & $2013: 265$ \\
\hline $\begin{array}{l}\text { Long-Term Relationship Bargaining } \\
\text { by Andreas Westermark }\end{array}$ & $2013: 266$ \\
\hline $\begin{array}{l}\text { Using Financial Markets To Estimate the Macro Effects of Monetary Policy: An Impact-Identified FAVAR* } \\
\text { by Stefan Pitschner }\end{array}$ & $2013: 267$ \\
\hline $\begin{array}{l}\text { DYNAMIC MIXTURE-OF-EXPERTS MODELS FOR LONGITUDINAL AND DISCRETE-TIME SURVIVAL DATA } \\
\text { by Matias Quiroz and Mattias Villani }\end{array}$ & $2013: 268$ \\
\hline $\begin{array}{l}\text { Conditional euro area sovereign default risk } \\
\text { by André Lucas, Bernd Schwaab and Xin Zhang }\end{array}$ & $2013: 269$ \\
\hline $\begin{array}{l}\text { Nominal GDP Targeting and the Zero Lower Bound: Should We Abandon Inflation Targeting?* } \\
\text { by Roberto M. Billi }\end{array}$ & $2013: 270$ \\
\hline $\begin{array}{l}\text { Un-truncating VARs* } \\
\text { by Ferre De Graeve and Andreas Westermark }\end{array}$ & $2013: 271$ \\
\hline $\begin{array}{l}\text { Housing Choices and Labor Income Risk } \\
\text { by Thomas Jansson }\end{array}$ & $2013: 272$ \\
\hline $\begin{array}{l}\text { Identifying Fiscal Inflation* } \\
\text { by Ferre De Graeve and Virginia Queijo von Heideken }\end{array}$ & $2013: 273$ \\
\hline
\end{tabular}



Sveriges Riksbank

Visiting address: Brunkebergs torg 11

Mail address: se-103 37 Stockholm

Website: www.riksbank.se

SVERIGES Telephone: +46 878700 00, Fax: +46 8210531

RIKSBANK E-mail: registratorn@riksbank.se 